\title{
SURABAYA SINGLE WINDOW SEBAGAI BENTUK INOVASI PELAYANAN PERIZINAN DI KOTA SURABAYA
}

\author{
Narwastu Widyan Suryaning Asri ${ }^{1}$, Isro’ Lailia ${ }^{2}$, Gisti Raisy Ismiartha ${ }^{3}$ \\ 1,2,3 Universitas Diponegoro \\ $e$-mail : ${ }^{1}$ narwastuwidyan@gmail.com, ${ }^{2}$ isrolailia18@ gmail.com, ${ }^{3}$ gisti.raisy@ gmail.com
}

\begin{abstract}
Fast and effective public services are a supporter of public administration so that continuous innovation is needed to improve the quality of public services. The city of Surabaya as one of the cities with the title of smart city has tried to always make innovations in an effort to improve the quality of public services, one of which is through the Surabaya Single Window. Surabaya Single Window is an online-based licensing service created to create effective public services. This article attempts to describe how the licensing service innovation carried out by the City Government of Suraya through the Surabaya Single Window covers five important aspects. The method used is descriptive qualitative using secondary data. It was found that the City of Surabaya succeeded in creating public service innovations through the Surabaya Single Window. The Surabaya Single Window has a positive impact on licensing services in the City of Surabaya, although in its implementation there are still certain guarantees.
\end{abstract}

Keywords: e-government, innovation, public service

\begin{abstract}
Abstrak
Pelayanan publik yang cepat dan efektif merupakan salah satu pendukung penyelenggaraan pemerintahan sehingga diperlukan inovasi yang berkelanjutan untuk meningkatkan kualitas pelayanan publik. Kota Surabaya sebagai salah satu kota dengan predikat smart city selalu berusaha melakukan inovasi dalam upaya meningkatkan kualitas pelayanan publik salah satunya melalui Surabaya Single Window. Surabaya Single Window adalah layanan perizinan berbasis online yang dibuat untuk mewujudkan pelayanan publik yang efektif. Artikel ini mencoba memaparkan bagaimana inovasi layanan perizinan yang dilakukan oleh Pemerintah Kota Suraya melalui Surabaya Single Window mencakup lima aspek penting. Metode yang digunakan adalah deskriptif kualitatif dengan menggunakan data sekunder. Kota Surabaya berhasil menciptakan inovasi pelayanan publik melalui Surabaya Single Window. Surabaya Single Window berdampak positif terhadap pelayanan perizinan di Kota Surabaya, walaupun dalam pelaksanaannya masih ada jaminan tertentu.
\end{abstract}

Kata kunci: e-government, inovasi, layanan publik

\section{PENDAHULUAN}

Pelayanan publik yang cepat dan efektif merupakan kunci keberhasilan dari administrasi publik. Oleh karena itu diperlukan adanya berbagai inovasi yang mengikuti perkembangan jaman sebagai upaya percepatan peningkatan pelayanan publik. Inovasi (Sedarmayanti, 2013:230) dapat diartikan sebagai upaya menghasilkan suatu produk maupun jasa baru yang bertujuan untuk meningkatkan kualitas suatu produk. Dalam kaitannya dengan pelayanan publik maka inovasi dapat didefinisikan sebagai upaya upaya yang dilakukan untuk meningkatkan kualitas pelayanan publik.
Kota Surabaya merupakan salah satu kota di Indonesia yang telah berupaya melakukan inovasi yakni melalui penerapan konsep "Smart City". Kementerian Dalam Negeri (Hasibuan, 2019: 127) mendefiniskan Smart City sebagai suatu perpaduan antara penataan kota yang terintegrasi dan penggunaan teknologi informasi dan komunikasi yang bertujuan untuk menciptakan kota yang modern dan layak huni. Salah satu upaya yang telah dilakukan Pemerintah Kota Surabaya dalam rangka perwujudan Smart City adalah dengan memberikan pelayanan publik yang cepat dan efisien yang diwujudkan melalui penerapan $e$ government. 
Saat ini Kota Surabaya telah menerapkan sistem pelayanan berbasis online dalam berbagai bidang, salah satunya adalah melalui inovasi Surabaya Single Window yang merupakan salah satu perwujudan $e$ government di Kota Surabaya yang berada dibawah Dinas Cipta Karya dan Tata Ruang. Surabaya Single Window merupakan suatu aplikasi yang dapat digunakan dalam mempermudah pelayanan publik dalam bidang perizinan. Dinas Cipta Karya dan Tata Ruang terhubung dengan SKPD lain yang dikoordinasikan oleh Dinas Komunikasi dan Informatika. Pada akhirnya terdapat Unit Pelayanan Terpadu Satu Atap yang menjadi tempat untuk melakukan verifikasi bagi pemohon perizinan. Adanya sistem pelayanan berbasis online, masyarakat dapat melakukan berbagai perizinan dengan lebih mudah, namun dalam penerapannya masih terdapat beberapa warga yang belum paham mengenai bagaimana cara melakukan perizinan melalui Surabaya Single Window.

Jika meninjau Surabaya Single Window segi inovasi sebagai salah satu bentuk implementasi smart city, maka penelitian ini akan membahas mengenai bagaimana analisa inovasi Surabaya Single Window sebagai bentuk pelayanan perizinan di Kota Surabaya melalui enam tipologi inovasi?

\section{KAJIAN PUSTAKA}

\section{Inovasi}

Susanto (2010: 158) menyebutkan bahwa inovasi merupakan penemuan baru yang berbeda dari yang pernah ada sebelumnya atau yang telah dikenal sebelumnya sebagai inovasi. Inovasi memiliki makna yang tidak sebatas membangun dan membarui namun juga dapat didefiniskan lebih luas, yaitu memanfaatkan ide atau penemuan baru untuk menciptakan produk, proses dan suatu layanan.

Definisi tersebut didukung oleh definisi yang dikemukakan oleh Sedarmayanti (2013: 231) yang menyatakan bahwa inovasi meliputi penciptaan sesuatu yang tidak ada saat ini dan dapat berupa penciptaan kecil atau sesuatu yang monumental. Sementara Oslo Manual (dalam Zuhal, 2013: 58) menyatakan bahwa inovasi memiliki aspek yang luas karena dapat berupa barang maupun jasa, proses, metode pemasaran atau metode organisasi yang baru atau telah mengalami pembaharuan yang menjadi jalan pelayanan, budaya birokrasi dan sebagainya.

Sehingga, dapat disimpulkan bahwa inovasi merupakan suatu bentuk penemuan yang belum pernah ada sebelumnya atau sebagai suatu pengembangan dari sesuatu yang telah ada sebelumnya, adapun inovasi dapat meliputin berbagai bentuk seperti jasa, proses, metode dan lain sebagainya.

\section{Tipologi Inovasi Sektor Publik}

Inovasi Sektor Publik memiliki beberapa tipologi, Halverson, dkk (2005: 2-3) membaginya menjadi enam tipologi: a). a new or improved service (pelayanan baru atau pelayanan baru atau pelayanan yang diperbaiki), misalnya kesehatan di rumah; b) process innovation (inovasi proses), misalnya perubahan dalam proses penyediaan pelayanan ke arah yang lebih baik atau sesuai dengan kebutuhan; c) administrative innovation (inovasi administratif), misalnya penggunaan instrumen kebijakan baru sebagai hasil dari perubahan kebijakan; d) system innovation (inovasi sistem), adalah suatu sistem baru atau suatu perubahan mendasar dari sistem yang ada dengan mendirikan organisasi baru atau bentuk baru dari sebuah kerjasama dan interaksi; e) conceptual innovation (inovasi konseptual), adalah perubahan dalam outlook, contohnya manajemen air terpadu atau mobility leasing; f) radical change of rational (perubahan radikal), yang dimaksud adalah pergeseran pandangan umum atau mental matriks dari pegawai instansi pemerintah.

\section{METODE PENELITIAN}

\section{Jenis Penelitian}

Jenis penelitian yang digunakan untuk penelitian ini yaitu penelitian kualitatif. Penelitian kualitatif merupakan metode-metode untuk mengeksplorasi dan memahami makna yang oleh sejumlah individu atau sekelompok orang dianggap berasal dari masalah sosial atau kemanusiaan (Creswell, 2014 : 4).

\section{Ruang Lingkup atau Objek Penelitian}

Objek penelitian dalam penelitian ini adalah Inovasi Surabaya Single Window (SSW) 
sebagai suatu bentuk inovasi pelayanan perizinan di Kota Surabaya.

\section{Bahan dan Alat Utama}

Bahan yang diperlukan dalam penelitian ini yaitu data yang berkaitan dengan Surabaya Single Window. Adapun alat-alat yang digunakan selama kegiatan penelitian yaitu (handphone, laptop, alat tulis)

\section{Tcmpat Penelitian}

Penelitian dilakukan melalui studi data sekunder atau kajian literatur dengan menggunakan berbagai jurnal penelitian terdahulu hingga menganalisa media massa kredibel yang memberikan informasi mengenai program Surabaya Single Window (SSW).

\section{Teknik Pengumpulan Data}

Pengumpulan data di penelitian ini menggunakan studi pustaka. Studi kepustakaan menurut Sugiyono (2014) berkaitan dengan kajian teoritis dan referensi lain yang berkaitan dengan nilai, budaya dan norma yang berkembang pada situasi sosial yang diteliti, selain itu studi kepustakaan sangat penting dalam melakukan penelitian, hal ini dikarenakan penelitian tidak akan lepas dari literatur-literatur ilmiah.

\section{Definisi Operasional}

a. A New or Improved Service

- Permasalahan yang mendasari pembuatan inovasi Surabaya Single Window (SSW).

- Standar pelayanan dan persyaratan yag ditetapkan dalam inovasi Surabaya Single Window (SSW).

- Perbedaan mendasar sebelum dan sesudah adanya inovasi Surabaya Single Window (SSW).

b. Process Innovation

- a. Peraturan yang mendasari pembuatan inovasi Surabaya Single Window (SSW).

- b. Apa yang akan dirasakan masyarakat, lebih mudah atau lebih sulit.

c. Administrative Innovation

- a. Penyampaian inovasi Surabaya Single Window (SSW) kepada masyarakat.
- Bantuan pengembangan inovasi Surabaya Single Window (SSW).

d. Inovasi Sistem

- Standar Operaional Prosedur yang dijalankan dalam inovasi Surabaya Single Window (SSW).

- Pengaruh aturan terhadap inovasi Surabaya Single Window (SSW).

- Kerjasama pemangku kepentingan dalam inovasi Surabaya Single Window (SSW).

e. Inovasi Konsep

- Kaitan inovasi Surabaya Single Window (SSW) dengan pelayanan publik.

f. Radical Change

- Pandangan masyarakat terhadap inovasi Surabaya Single Window (SSW).

- Perubahan setelah adanya inovasi Surabaya Single Window (SSW).

\section{HASIL DAN PEMBAHASAN}

Berdasarkan hasil pengumpulan data yang telah dilakukan, berikut merupakan penerapan inovasi Surabaya Single Window dilihat dari enam tipologi inovasi:

\section{A New or Improved Service}

A new or improved service (pelayanan baru atau pelayanan yang diperbaiki) memiliki arti apakah inovasi-inovasi yang dikeluarkan pemerintah saat ini sudah sesuai dengan kebutuhan atau masih perlu dilakukan perbaikan. A New or improved service dapat dilihat dari tiga hal yaitu apa yang mendasari munculnya sebuah inovasi, persyaratan atau standar-standar yang ditetapkan dalam pembuatan inovasi, serta perbedaan mendasar sebelum dan setelah adanya inovasi.

Inovasi Surabaya Single Window merupakan inovasi pelayanan pemerintahan Kota Surabaya. Inovasi tersebut diluncurkan sejak 14 Maret 2013. Adanya berbagai permasalahan pelayanan yaitu panjangnya birokrasi, sistem perijinan yang kurang transparan, serta lamanya waktu penyelesaian perijinan menjadi alasan munculnya inovasi Surabaya Single Window ini. Adanya inovasi tersebut pemerintah berharap dapat membantu urusan masyarakat kaitannya dalam hal perizinan. Munculkan inovasi ini, memudahkan masyarakat untuk mengurus perizinan tanpa harus datang ke berbagai 
instansi terkait perizinan tertentu karena perizinan dapat dilakukan secara online.

Sebuah inovasi pastinya memiliki standarstandar pelayanan yang harus dipenuhi agar sebuah pelayanan dapat memberikan kepuasan kepada masyarakat. Standar pelayanan dalam inovasi Surabaya Single Window mengacu pada Undang-Undang Nomor 25 Tahun 2009 tentang Pelayanan Publik. Pada UndangUndang tersebut dijelaskan bahwa komponen standar pelayanan dibagi menjadi dua yaitu standar pelayanan yang berkaitan dengan proses penyampaian pelayanan serta standar pelayanan yang terkait dengan proses pengelolaan pelayanan di internal organisasi. Standar pelayanan Surabaya Single Window berdasarkan UU Nomor 25 Tahun 2009 telah dirinci dalam lampiran Keputusan Kepala Badan Koordinasi Pelayanan dan Penanaman Modal Kota Surabaya Nomor 503/4435/436.7.5/2015. Pada lampiran tersebut sudah dijelaskan secara detail bagaimana sistem, mekanisme, prosedur, biaya, jangka waktu, dasar hukum, kompetensi pelayan, sarana dan prasana serta komponen lainnya yang sesuai dengan standar pelayanan.

Waktu merupakan perbedaan mendasar yang terlihat sebelum dan setelah adanya inovasi Surabaya Single Window. Sebelum adanya inovasi Surabaya Single Window, proses perijinan di Kota Surabaya cenderung lama. Misalnya saja apabila seorang pemohon akan mengajukan 3 buah perijinan harus menunggu satu perijinan selesai setelah itu baru bisa mengajukan permohonan ijin lainnya. Akan tetapi setelah adanya inovasi tersebut, proses perijinan dapat dilakukan secara bersamaan. Masyarakat pemohon hanya membutuhkan waktu 14 sampai 30 hari untuk mendapatkan ijin yang dibutuhkan. Selain waktu, perbedaan yang terlihat setelah adanya inovasi Surabaya Single Window yaitu berkurangnya calo-calo dalam proses pelayanan perizinan.

\section{Process Innovation}

Process inovation memiliki arti bahwa sebuah inovasi merupakan suatu proses perubahan dalam hal pelayanan ke arah yang lebih baik. Process Innovation dapat dilihat dari dua hal yaitu aturan khusus dan jaminan pelayanan.
Inovasi Surabaya Single Window merupakan inovasi yang di dasarkan pada tujuan pemerintah terkait dengan reformasi birokrasi dan pelayanan publik. Pemerintah baik pusat maupun daerah memiliki tujuan untuk menciptakan birokrasi yang efektif dan efisien salah satunya melalui inovasi-inovasi. Peraturan yang mendasari dibentuknya inovasi Surabaya Single Window yaitu Peraturan Walikota Surabaya Nomor 28 Tahun 2013 tentang Tata Cara Pelayanan Perizinan dan Non Perizinan Secara Elektronik di Kota Surabaya dan Peraturan Walikota Surabaya Nomor 55 Tahun 2015 tentang Integrasi Pelayanan Perizinan dan Non Perizinan di Kota Surabaya.

Adanya inovasi Surabaya Single Window masyarakat memiliki jaminan berupa ketepatan waktu, persyaratan, serta biaya. Petugas memberikan jaminan ketepatan waktu kepada masyarakat pemohon dimana pelayanan perizinan hanya membutuhkan waktu 14 sampai 30 hari. Hal tersebut berbeda dengan sebelum adanya inovasi Surabaya Single Window dimana pelayanan perizinan lebih banyak memakan waktu karena panjangnya birokrasi. Seringkali pelayanan perizinan juga berhenti di satu tahap dan masyarakat pemohon tidak mengetahuinya.

Inovasi Surabaya Single Window memberikan jaminan persyarakat dimana pemohon aka diberi tahu apa saja berkas persyaratan yang dibutuhkan. Melalui Surabaya Single Window yang berbasi online, apabila berkas dokumen tidak lengkap maka tidak mungkin bisa di proses. Sebelum adanya inovasi, ketika pemohon mengajukan perizinan seringkali berhenti di tengah jalan dikarenakan berkas yang tidak lengkap dan mereka tidak mengetahuinya. Adanya inovasi perizinan secara online ini, masyarakat pemohon bisa memantau sampai dimana permohonan mereka di proses dan kapan kemungkinan proses perizinan selesai.

Selanjutnya yaitu jaminan biaya. Pelayanan perizinan yang dilakukan secara online akan mengurangi intensitas tatap muka antara pemohon dan petugas pelayanan. Hal tersebut tentunya akan mengurangi kemungkinan adanya biaya tambahan setiap proses perizinan serta mengurangi adanya calo dalam proses perizinan.

\section{Administrative Innovation}


Administrative Innovation merupakan salah satu dari enam tipologi inovasi sektor publik yang memiliki fokus terhadap pemberian informasi serta bantuan dalam pengembangan inovasi.

- Administrative innovation yang berfokus pada pemberian inovasi memiliki peran yang sangat penting sebab informasi menjadi salah satu kunci keberhasilan inovasi Surabaya Single Window (SSW). Berdasarkan hasil analisa penulis terhadap berbagai sumber literatur, diketahui bahwa penyebaran informasi dilakukan melalui sosialisasi sejak peluncuran program ini dilakukan pada 14 Maret 2013. sosialisasi dilakukan dengan mendatangkan para anggota organisasi dari lini pengusaha dan konsultan yang sering melakukan proses perijinan. Adapun terdapat 3 sosialisasi dilakukan meliputi penyelenggaraan forum dengan mengundang SKPD terkait, media massa dan dan para stakeholders, pengadaan brosur, bangger dan selebaran mengenai program SSW, serta sosialisasi melalui media sosial facebook yang bekerjasama dengan Media Cender Pemerintah Kota Surabaya.

- Hal mengenai penyebaran informasi sudah dikatakan berhasil dibuktikan dengan semakin banyaknya masyarakat serta investor yang tahu mengenai manfaat dari penggunaan program tersebut.

\section{Inovasi Sistem}

Inovasi sistem merupakan bagian dari tipologi inovasi sektor publik yang berfokus pada sistem inovasi pelayanan serta kerjasama yang dilakukan antar stakeholders dalam melaksanakan inovasi pelayanan publik.

- Sistem inovasi merujuk pada perubahan yang terjadi setelah adanya inovasi, yang berkaitan dengan dasar hukum suatu inovasi serta Standar Operasional Prosedur (SOP). Dasar hukum yang digunakan pada Surabaya Single Window (SSW) adalah Peraturan Walikota Surabaya Nomor 28 Tahun 2013 Tentang Tata Cara Pelayanan Perizinan dan Non Perizinan Secara Elektronik di Kota Surabaya yang selanjutnya menjadi dasar dalam pelaksanaan Surabaya Single Window. Selain itu, SOP juga menjadi unsur penting dalam perwujudan inovasi sistem. Apabila suatu layanan publik memiliki SOP yang jelas dan mudah dipahami maka masyarakat akan dengan mudah menggunakan layanan publik tersebut dan tidak kebingungan apabila suatu saat menemui suatu kendala. Surabaya Single Window telah memiliki SOP, namun pada penerapannya belum terlaksana secara efektif karena pemohon masih harus datang ke UPTSA untuk melakukan verifikasi berkas.

- Kerja sama merujuk pada berbagai upaya yang dilakukan seluruh stakeholders yang terlibat dalam pelaksanaan Surabaya Single Window. Terdapat beberapa pihak yang terlibat dalam inovasi Surabaya Single Window, diantaranya meliputi delapan SKPD, masyarakat, dan investor. Dalam hal ini Dinas Komunikasi dan Informatika dan Dinas Penanaman Modal dan Pelayanan Terpadu Satu Pintu Kota Surabaya merupakan pengelola utama dalam Inovasi Surabaya Single Window dan UPTSA (Unit Pelayanan Terpadu Satu Atap) sebagai pelaksana inovasi. Kerja sama yang dilakukan antar SKPD dalam pelaksanaan Surabaya Single Window terbilang cukup baik walaupun masih terdapat beberapa kendala.

\section{Inovasi Konsep}

Inovasi konsep melihat pada konsep perubahan yang dirasakan oleh pembuat inovasi maupun masyarakat sebagai sasaran inovasi. Inovasi konsep dalam Inovasi Surabaya Single Window berfokus pada perubahan terkait dengan kinerja pelayanan publik. Surabaya Single Window sendiri bertujuan untuk mewujudkan pelayanan publik yang transparan, efektif, dan efisien. Sebelum adanya Surabaya Single Window, seluruh pelayanan perizinan dilakukan secara manual sehingga masyarakat harus datang ke SKPD terkait untuk mengajukan permohonan perizinan. Hal ini menyebabkan pembludakan jumlah pemohon yang datang ke SKPD sehingga berakibat pada lamanya jangka waktu pelayanan dan petugas pun akan kewalahan.

Setelah adanya Inovasi Surabaya Single Window, pelayanan perizinan menjaid lebih mudah diakses karena dapat dilakukan dimana saja sehingga pemohon tidak harus meninggalkan aktivitasnya untuk datang dan mengantri di kantor pelayanan perizinan. Selain 
itu, Surabaya Single Window menerapkan sistem paralel dalam pelaksanaan pelayanan perizinan. Pemohon dapat melakukan permohonan perizinan beberapa jenis dokumen secara bersamaan dan dokumen dapat selesai lebih cepat yakni selama 14 sampai 30 hari tergantung jumlah dan jenis dokumen dan pemohon dapat mematau status dokumennya melalui website SSW. Inovasi ini telah berhasil memangkas alur birokrasi dalam prosedur pelayanan perizinan di Kota Surabaya dan memungkinkan terwujudnya pelayanan publik yang efektif dan efisien.

\section{Radical Change}

Radical Change atau perubahan radikal merupakan salah satu tipologi yang berfokus pada pola pikir atau pandangan terhadap suatu inovasi dari pihak internal atau para pegawai dari instansi tempat inovasi tersebut diluncurkan. Berdasarkan hasil kajian literatur yang dilakukan oleh penulis, diketahui bahwa para pengelola inovasi tersebut merasa tercukupi karena diselenggarakannya pelatihan dalam pengelolaan sistem yang mendukung kemampuan mereka sehingga mampu menguasai sistem yang memudahkan pelayanan bagi masyarakat pengguna SSW. Selain itu, dampak positif lain yang dirasakan adalah peningkatan efektivitas dalam organisasi karena adanya ketentuan bagi para SKPD terkait untuk tidak diperbolehkan memegang berkas mampu meminimalkan kiberja pada SKPD yang bersangkutan.

\section{KESIMPULAN}

Adanya inovasi Surabaya Single Window memberikan perubahan yang lebih baik lagi bagi proses pelayanan perizinan di Kota Surabaya. Proses perizinan dijamin lebih cepat karena sudah diatur standar bahwa proses pelayanan selesai dalam $14-30$ hari. Pengerjaan berbagai perizinan juga bisa dilaksanakan secara bersama-sama. Penggunaan teknologi dalam proses perizinan juga meningkatkan efektifitas, efisiensi serta keterbukaan proses pelayanan. Meskipun membawa berbagai perubahan yang positif, masih terdapat masalah dimana terdapat beberapa masyarakat yang belum paham bagaimana mengurus perizinan melalui Surabaya Single Window. Adanya permasalahan tersebut, pemerintah dapat membuat tutorial cara mengurus perizinan melalui Surabaya Single Window yang nantinya dapat dijadikan sebagai media sosialisasi.

\section{REFERENSI}

\section{$\underline{\text { Buku }}$}

Creswell, John W. (2014). Research Design Pendekatan Kualitatif, Kuantitatif, Dan Mixed. Yogyakarta: Pustaka Pelajar.

Sedarmayanti. (2013). Reformasi Administrasi Publik, Reformasi Birokrasi, dan Kepemimpinan Masa Depan (Mewujudkan Pelayanan Prima dan Kepemerintahan yang Baik). Bandung : Refika Aditama.

Sugiyono. (2014). Metode Penelitian Kuanttatif, Kualitatif, Dan $R \& D$. Bandung: Alfabeta.

Susanto. (2010). 60 Manajemen Gems. Jakarta: Kompas.

Zuhal. (2013). Gelombang Ekonomi Inovasi: Kesiapan Indonesia Berselancar di Era Ekonomi Baru. Jakarta: PT Gramedia Pustaka Utama

\section{Jurnal Ilmiah}

Baharudinsyah, Achmad. (2018). Pengaruh Efektivitas Program dan Standar Operasional Prosedur Surabaya Single Window di Dalam Peningkatan Kualitas Pelayanan di Unit Pelayanan Terpadu Satu Atap (UPTSA) Surabaya. Skripsi. Universitas Airlangga.

Basuki, Yayuk, dkk. (2018). Tipologi Inovasi Sektor Publik (Inovasi Program SiCakep) Di Kabupaten Wajo, Sulawesi Selatan. Mantra Pembaharuan, Volume 2, Nomor 3, Halaman 207-216.

Carlolina, Lisa Ananda. (2020). Reformasi Birokrasi di Unit Pelayanan Terpadu Satu Pintu (UPTSA) Melalui Surabaya Single Windows. Jurnal Mahasiswa Administrasi Negara, Volume 4, Nomor 1.

Hasibuan, Abdurrozzaq, Oris Krianto Sulaiman. (2019). Smart City, Konsep Kota Cerdas Sebagai Alternatif Penyelesaian Masalah Perkotaan Kabupaten/Kota, di Kota-kota Besar 
Provinsi Sumatera Utara. Buletin Utama

Teknik Vol. 14, No. 2: 127-135

Kirana, Cintantaya Andhita Dara. (2017). Monitoring dan Evaluasi Program "Surabaya Single Window" Sebagai Bentuk Electronic Government Di Kota Surabaya. Jurnal Pembangunan dan Kebijakan Publik, Volume 8, Nomor 01, Halaman 43-52.

Pradhina, Indah Putri dan Teguh Yuwono. (2019). SSW (Surabaya Single Window) : Inovasi Sistem Pelayanan Terintegrasi Berbasis Elektronik terhadap Perwujudan Akuntabilitas Publik Unit Pelayanan Terpadu Satu Atap Kota Surabaya.E Journal UNDIP.

Romadhon, Rifki. (2015). Terobosan Inovasi Perizinan Online Terpadu melalui Surabaya Single Window di Kota Surabaya. Jurnal Transformative, Volume 1, Nomor 2.

\section{Peraturan - peraturan}

Keputusan Kepala Badan Koordinasi Pelayanan dan Penanaman Modal Kota Surabaya Nomor 503/2045/436.7.5/2013

Peraturan Walikota Surabaya Nomor 28 Tahun 2013 tentang Tata Cara Pelayanan Perizinan dan Non Perizinan Secara Elektronik di Kota Surabaya. 